\title{
CÂTEVA CONSIDERATII PE MARGINEA PROIECTULUI DE MODIFICARE A LEGII NR. 514/2003 PRIVIND ORGANIZAREA ŞI EXERCITAREA PROFESIEI DE CONSILIER JURIDIC
}

\author{
DOI:10.24193/SUBBiur.62(2017).1.8 \\ Published Online: 2017-03-15 \\ Published Print: 2017-03-30
}

\begin{abstract}
Andra HUIDAN*
Abstract: A few considerations regarding the draft law amending Law 514/2003 on the exercise and practice of the legal adviser profession. Over the past few years, the legislation regarding legal advisors has made the object of two attempts to reform. None of the two bills passed by a vote in Parliament and so, the legal framework remains as it is, despite its multiple flaws and inadequacies caused by the lack of adaptation to current realities. Unlike other legal professions, the legal advisor practices under the authority of his employer, which gives him the statute of an employee rather than the one afferent to a free practicioner. The possibility of private legal practice is a non-existent option in the current state of the legislation. The article analyzes the amendments the two bills proposed, which follow the line of improvement towards professional independence, thoroughly organised professional associations and, nonetheless, means of increasing self-performance as one of the legal professions in the judicial system. All of the above are subsequent to a series of debates between members of the Legal Advisors College and representatives of the National Union of Romanian Bars.
\end{abstract}

Keywords: private legal practice, legal advisor, professional performance, legal compartments, professional independence

Cuvinte cheie: societăți civile profesionale, consilier juridic, pregătire profesională, compartimente judiciare, independență profesională

Legea nr. 514/2003 privind organizarea și exercitarea profesiei de consilier juridic a făcut, de-a lungul timpului, obiectul a doua inițiative legislative de modificare a parametrilor de exercitare a profesiei, ambele proiecte fiind respinse de către Parlament. Primul proiect de lege, care a vizat modificarea statutului consilierului juridic, PI. $x-n r$. 312/2010 ${ }^{1}$, a fost respins definitiv de către Camera Deputaților, într-o conjunctură diametral opusă față de cea în care se află actualul proiect. PI. x - nr. 312/2010 a fost adoptat, într-o primă etapă, de către Senat. Cea de-a doua inițiativă legislativă de modificare, proiectul Legii nr. 138/2016 privind modificarea şi completarea Legii nr. 514/2003 privind organizarea şi exercitarea profesiei de consilier juridic precum şi a Legii nr. 200/2004 privind recunoaşterea diplomelor şi 
calificărilor profesionale pentru profesiile reglementate din România, cu modificările şi completările ulterioare, urmând regimul legilor organice, este plasat, pentru adoptare, către Camera Deputaților, aceasta fiind camera decizională, care va fi sesizată ulterior, după votul Senatului. Legea nr. 138/2016, a fost respinsă de către Senat, cu majoritate de voturi, în cadrul ședinței din 27.06.2016². Cu toate că legea așteaptă votul decizional definitiv al Camerei Deputaților, aflându-se în prezent în dezbaterea acestei camere, adoptarea dispozițiilor legislative pare o alternativă distantă și improbabilă în contextul necesităților de reformare a profesiei de consilier juridic. Membrii ai Senatului, organe reprezentative ale U.N.B.R, cât și Guvernul au exprimat puncte de vedere negative referitoare la modificările propuse.

Restructurarea profesiei, astfel cum s-a dorit în anul 2009, prin intermediul PI. xnr. 312/2010, a vizat însăși natura publică, respectiv privată a acestei profesii, care se regăsește în Codul Ocupațiilor din România sub denumirea de "consilier juridic" sau "consultant juridic". În funcție de grupa de ocupații din care face parte, consilierul juridic aparține Specialiștilor în domeniul juridic, iar consultantul juridic, având un nivel de studii nedefinit de către Codul COR, aparține grupei de bază a Înalților conducători ai administrației publice. Acest caracter de subspecie este reliefat și în cazul primei categorii, al cărei indicator stabilește ca și grupă de bază pe cea a avocaților ${ }^{3}$. Pornind de la aceste precizări, vom analiza punctual încercarea de modificare a statutului profesiei prin raportare la structurile publice în care consilierul juridic își desfășoară activitatea, atrăgând atenția asupra lacunei legislative care s-ar fi creat prin adoptarea PI. x - nr. 312/2010, dispozițiile acestuia lăsând în afara sferei de aplicare a legii, consilierul juridic angajat, în baza unui contract individual de munca, în cadrul unei întreprinderi, societăți private.

Astfel, potrivit art. 1, 2 și 3 ale Legii nr. 514/2003 privind organizarea și exercitarea profesiei de consilier juridic, în forma sa actuală, consilierul juridic poate să fie numit în funcție sau angajat în muncă, urmând să aibă statutul unui funcționar public, respectiv al unui salariat și este acea persoană care asigură apărarea drepturilor și intereselor legitime ale statului, ale autorităților publice centrale și locale, ale instituțiilor publice și de interes public, precum și ale persoanelor juridice de drept privat, în slujba cărora se află. Scindând modurile de exercitare a profesiei și într-o optică inedită din perspectiva cadrului de muncă al consilierului juridic, PI. x-nr. 312/2010 păstra în sfera de aplicabilitate a legii și a statutului profesiei doar persoana care își exercită atribuțiile în slujba persoanelor juridice de drept public, art. 3 al acestui text de lege prevăzând că este asimilată unui magistrat persoana care își desfășoară activitatea în cadrul autorităților administrației publice centrale, locale și județene, precum și a instituțiilor publice corespunzătoare. Art. 1 al (2) mai prevedea că au calitatea de consilieri juridici "numai persoanele care își desfășoară activitatea în compartimentele judiciare prevăzute de prezenta lege"4. Proiectul ar fi impus ca la nivelul autorităților administrației publice centrale, județene și locale să fie constituite anumite structuri judiciare, în cadrul cărora să își desfășoare activitatea consilieri juridici numiți în funcție sau angajați in muncă, aceștia fiind singurii care ar urma să beneficieze de prevederile Legii nr. 514/2003 și implicit, de statutul magistratului, având drepturi și obligații similare.

Compartimentele judiciare menționate mai sus, pot fi clasificate în 3 categorii, în funcție de autoritatea publică în cadrul căreia ar fi urmat să funcționeze. Astfel, potrivit art. 24 al PI. x - nr. 312/2010 direcțiile generale judiciare ar fi fost constituite la nivelul 
administrației publice centrale, al prefecturilor și al consiliilor județene, direcțiile judiciare ar fi urmat să funcționeze în cadrul consiliilor locale, iar la nivelul instituțiilor publice, în funcție de structura acestora, urmau să funcționeze birouri și servicii judiciare. Aceste unități ar fi fost subordonate numai Consiliului Superior al Magistraturii. Stabilirea modului de organizare și al numărului posturilor disponibile a fost plasată în sarcina Ministerului de Justiție, iar numirea directorilor acestor structuri urma să fie făcută de către președinte prin decret, într-un mod asemănător celui în care sunt numiți judecătorii.

În anticiparea dificultăților pe care o astfel de soluție legislativă le-ar fi atras, instituind minimul subordonării pur administrative a unui departament al autorității publice față de structura în cadrul căreia acesta funcționează, principala critică de la acea vreme a fost în legătură cu asimilarea statutului consilierilor juridici cu cel al magistraților, în temeiul mai multor prevederi. Textul proiectului de lege ridica probleme de constituționalitate, sub acest aspect. Magistratura, ca și activitate judiciară, deși este definită în Legea nr. 303/2004, iar nu în textul Constituției, este desfășurată doar de către judecători și procurori, aspect consacrat atât la nivel constituțional, prin enumerarea entităților care fac parte din autoritatea judecătorească (instanțele judecătorești și Ministerul public), cât și la nivelul legislației primare, prin ancorarea activității în anumite scopuri limitativ enumerate în art. 1 al Legii nr. 303/2004. Astfel că, deși apreciem neconstituționalitatea textelor analizate doar prin raportare la scopul desfășurării activității judiciare, astfel cum este cuprins în art. 124 și art. 131 ale Constituției, adoptarea PI. x - nr. 312/2010 ar fi presupus o extindere a noțiunii de "magistratura". Modificarea Legii nr. 303/2004 privind organizarea judiciara este una dintre schimbările pe care intrarea în vigoare a acestui proiect ar fi antamat-o, alături de modificarea unor dispoziții ale Legii nr. 215/2001 privind administrația publică locală, precum și ale Legii nr. 188/1999 privind Statutul funcționarilor publici, lege care încadrează consilierul juridic funcționând în cadrul unei autorități publice ca funcționar public.

Un aspect pozitiv al acestei asimilări cu totul inedite, propusă de către inițiatorii proiectului de lege, ar fi fost faptul că, activitatea publicistică salarizată ar fi devenit compatibilă cu exercitarea profesiei de consilier juridic, asemănător regimului incompatibilităților magistraților, precum și ale avocaților. Din acest punct de vedere, doctrina a susținut o restructurare a profesiilor juridice ${ }^{5}$.

Una dintre inadvertențele conținute în acest proiect privește caracterele profesiei și, mai precis, pe cel al independenței. Problematica independenței profesionale este încă actuală, fiind aspectul central al tuturor dezbaterilor privind restructurarea profesiei. $O$ distincție se impune a fi făcută, între independența opiniilor profesionale ale consilierului juridic, în exercitarea atribuțiilor sale și independența profesiei față de alte profesii juridice reglementate autonom, precum și față de structura în cadrul căreia consilierul juridic își desfășoară activitatea. Art. 5 al proiectului de modificare proclama consilierul juridic independent în exercitarea profesiei, asemenea magistratului, acesta supunându-se numai legii, statutului profesiei și codului deontologic profesional, în vreme ce art. 7 vorbește despre consilierii juridici "încadrațit" în compartimente judiciare constituite la nivelul autorităților administrației publice. Avem în vedere, referitor la modul în care ar fi funcționat cele două articole coroborate, independența profesională în latura sa privitoare la raporturile consilierului juridic cu beneficiarul serviciilor sale. Singurul mod consacrat legal prin care un 
consilier juridic poate presta activități în favoarea unei entități juridice este, și ar fi rămas și odată cu intrarea în vigoare a acestui proiect, încadrarea în muncă a consilierilor juridici prin numirea în funcție sau angajare în cadrul entității în slujba căreia își desfășoară activitatea, apărând drepturile acestei persoane juridice. Funcționarea compartimentelor judiciare în cadrul unor autorități publice, raporturile de muncă existente între consilierul juridic și beneficiarul serviciilor sale, precum și scopul activității desfășurate de către consilierul juridic, scop care nu poate excede intereselor autorității publice și implicit ale statului, fac ca acesta să nu poată fi caracterizat ca independent în exercitarea profesiei față de entitatea angajatoare, ci subordonat instituției în care funcționează. Deși s-a dorit ca profesia de consilier juridic să fie caracterizată de independența profesională de care se bucură magistratul, această asimilare nu este viabilă prin prisma scopului activității desfășurate. Astfel, scopul desfășurării activității judiciare de către judecător este înfăptuirea justiției, după cum cel al desfășurării activității judiciare de către procuror este cel al apărării ordinii de drept. Scopul activității desfășurate de către consilierul juridic este și ar fi rămas și în forma modificată a legii "apărarea drepturilor și intereselor legitime ale statului, ale autorităților publice centrale și locale, ale instituțiilor publice...în slujba cărora se află". Orice încercare de a caracteriza profesia de consilier juridic ca independentă prin prisma relației cu entitatea beneficiară, presupune ca și condiții sine qua non, eliminarea raporturilor de muncă, precum și, la nivel teoretic, identificarea interesului public în funcționarea organizațiilor profesionale ale consilierilor juridici. După cum s-a atras atenția în doctrină, consilierul juridic exercită un rol de prevenție referitor la situațiile litigioase ${ }^{6}$ în care este atrasă răspunderea entității ale cărei interese le apără, îndeplinindu-și în acest scop atribuțiile prevăzute de lege, precum și de alte acte emise de către instituția beneficiară a serviciilor sale.

De altfel, raporturile de muncă au ca situație premisă subordonarea, presupun imixtiuni de fond în activitatea consilierului juridic și mențin imposibilitatea acestuia de a-și organiza "afacerile" pe cont propriu". În acest sens s-a pronunțat și Curtea Constituțională prin Decizia nr. 101 din 27 februarie 2014, statuând că "profesia de consilier juridic, nefiind o profesie liberală asemenea celei de avocat, nu poate fi exercitată decât în limitele cadrului legal al raportului de serviciu (în condițiile prevăzute de Legea nr. 188/1999 privind Statutul funcționarilor publici) sau al raportului juridic de muncă (în urma încheierii unui contract individual de muncă în conformitate cu prevederile Codului muncii)". Subliniem astfel, că orice încercare de liberalizare a profesiei trebuie să aibă fundamentul interesului public în desfășurarea activității specifice, fundament care să se deosebească de exercitarea unei apărări calificate, pentru a evita apariția nejustificată a unor structuri paralele celor create în baza Legii nr. 51/1995, structuri a căror necesitate nu s-a conturat până în prezent.

Necesitățile de restructurare a profesiei de consilier juridic se datorează lipsei unui cadru asociativ coerent, exclusiv și cu drepturi depline în ceea ce privește profesia și membrii săi, precum și lipsei unui program de pregătire profesională continuă asemenea celui instituit pentru profesia de avocat. Nevoia imperioasă de perfecționare profesională se conturează în special în raport cu variatele obiecte de activitate ale entității ale cărei interese le apără, aspect care transformă consilierul juridic într-un simplu subordonat în desfășurarea unor activități de interes public sau privat, în antiteză cu profesionistul independent. Totuși, consilierul juridic poate fi pus în situația concretă de a exercita apărarea calificată în beneficiul entității angajatoare, 
reprezentând beneficiarul serviciilor sale în fața instanțelor judecătorești și a celorlalte autorități cu atribuții jurisdicționale. Tocmai pentru acest considerent, trebuie recunoscut consilierului juridic accesul la forme de pregătire și perfecționare profesională la standarde corespunzătoare. În această componentă a activității sale, interesul public este pregnant, iar lipsa reglementărilor în materie este de natură să afecteze calitatea activității consilierului juridic. Orice formă suplinitoare a acestei lacune prin subordonarea consilierilor față de Consiliul Superior al Magistraturii sau prin introducerea unei forme liberale de exercitare a profesiei în cadrul unor societăți profesionale este inutilă și creatoare de confuzii.

În strânsă legătură cu realizarea activității consilierului juridic, atât legea cât și proiectul de modificare în discuție recunosc consilierului independența opiniilor profesionale, inviolabilitatea lucrărilor și actelor cu caracter profesional, garanții care apar ca inerente unei profesii juridice organizate autonom și care se exercită integrat în sistemul de justiție românesc. În ceea ce privește ultima componentă a independenței consilierului juridic față de alte profesii organizate, aceasta este consacrată în cadrul art. 2 al Statutului profesiei și nu poate fi contestată, în condițiile dispozițiilor Legii nr. 514/2003.

PI. x - nr. 312/2010 mai impunea obligația consilierilor juridici de a se asigura pentru răspundere profesională, similar avocaților. Din toate aceste motive, proiectul de modificare a Legii nr. 514/2003 a fost respins cu majoritate de voturi de către Camera Deputaților, în anul 2010.

Într-o a doua încercare de modificare a legii profesiei și pornind de la dezideratul creării unei independențe profesionale parțiale, ${ }^{8}$ proiectul Legii nr. 138/2016 privind modificarea şi completarea Legii nr. 514/2003 privind organizarea şi exercitarea profesiei de consilier juridic precum şi a Legii nr. 200/2004 privind recunoaşterea diplomelor şi calificărilor profesionale pentru profesiile reglementate din România, cu modificările şi completările ulterioare a fost înregistrat la Senat pentru dezbatere în anul 2015, în procedură de urgență. În intervalul de timp scurs de la înregistrare și până la momentul votului negativ al acestei camere $(27.06 .2016)^{9}$, asupra modificărilor propuse s-au pronunțat, prin emiterea unor avize, Consiliul Legislativ, Guvernul, Comisia pentru muncă, familie şi protecție socială, Comisia pentru drepturile omului, culte şi minorități și Comisia pentru egalitatea de șanse.

Ca un corolar al independenței profesionale a consilierului juridic, proiectul de lege ${ }^{10}$ introduce o nouă formă de exercitare a profesiei prin societăți civile profesionale al căror unic obiect de activitate îl constituie principalele moduri în care consilierului juridic își realizează activitatea, astfel cum sunt consacrate la art. 4 al legii și care fac, la rândul lor, obiectul unor succinte modificări. Astfel, consilierul juridic își îndeplinește atribuțiile oferind asistență și consultanță juridică, reprezentând entitățile de interes public și privat in fața instanțelor judecătorești, redactând opinii juridice, proiecte de contracte, alte acte juridice, ocazie cu care acesta poate atesta identitatea părților, a conținutului, a datei și a consimțământului părților prin aplicarea parafei profesionale individuale conținând elemente de identificare ale Colegiului din care acesta face parte. Actuala forma a Legii nr. 514/2003 mai prevede printre activitățile consilierului juridic și avizarea și contrasemnarea actelor cu caracter juridic, verificarea legalității actelor, precum și semnarea, în cadrul reprezentării, a documentelor cu caracter juridic. Toate aceste atribuții corespund formelor subordonate de desfășurare a activității, ca și angajat sau ca și funcționar public în cadrul entităților private sau publice. 
Societatea civilă profesională vine în completarea celor două, entitate cu personalitate juridică, constituită în baza unui contract de societate de către unul sau mai mulți consilieri juridici definitivi și supusă unor formalități de înregistrare la Colegiul din județul în care societatea își are sediul. Acest Colegiu este responsabil și de înregistrarea filialelor constituite potrivit art. 2 al. (4). Textul legii nu menționează condiții suplimentare pentru înființarea societății, singura cerință fiind cea cu privire la calitatea asociaților. Dat fiind faptul că modul de organizare, funcționare și dizolvare al societății sunt lăsate de al. (7) al art. 2 în sarcina Congresului Consilierilor Juridici, Regulamentul ar putea să prevadă cerințe privind compunerea capitalului social, a duratei societății și a aporturilor consilierilor juridici definitivi asociați. Dorim să atragem atenția asupra calificării desuete a formei de exercitare a profesiei, aceasta nefiind în concordanță cu Legea nr. 71/2011 care prevede la art. 7 lit. c), înlocuirea sintagmei "societate civilă profesională" cu aceea a "societății profesionale", cu sau fără personalitate juridică, în cuprinsul tuturor actelor normative. Acest aspect a fost semnalat și în ceea ce privește Legea nr. 51/1995 ${ }^{11}$.

Activitatea care ar urma să fie desfășurată de către acești profesioniști ai dreptului a fost și ea diversificată prin includerea a doua noi tipuri de prerogative și atribuțiuni, noutăți pe care le regăsim în textul art. 4 al legii în dezbatere, spre deosebire de actuala reglementare care consacră activitățile consilierului juridic în textul art. 10, întro formă mai precisă. Noutățile constau în posibilitatea consilierului juridic de a atesta conținutul și data certă pentru validitatea actelor juridice întocmite și de a desfășura activități de conciliere, negociere, management și audit juridic.

Activitățile de negociere nu reprezintă o noutate absolută în ceea ce privește exercitarea profesiei, acestea sunt consacrate și în actuala reglementare cu o referire punctuală la clauzele contractuale. Activitățile de conciliere sunt cele care vin să completeze sfera formelor de activitate profesională a consilierului juridic, respectiv a serviciilor oferite în cadrul formei societare propuse. În concret, acestea pot avea scopul de a preîntâmpina apariția situațiilor litigioase sau de a stinge unele deja declanșate. Textul legii nu face nicio distincție sub acest aspect, astfel că, raportul dintre această activitate și cea desfășurată de către mediatori în baza Legii nr. 192/2006 nu se conturează cu claritate, obligativitatea vreunei autorizări suplimentare a consilierului nu este consacrată, iar o incompatibilitate de plano între cele două profesii nu există, din perspectiva art. 13 al Legii nr. 192/2006 ${ }^{12}$. Totuși, analizând textul Legii nr. 514/2003, în forma sa actuală, observăm faptul că profesia de consilier juridic este incompatibilă cu orice altă profesie autorizată sau salarizată în România. Textul Legii nr. 138/2016 modifică însă regimul incompatibilităților, eliminând incompatibilitatea activității cu cea publicistică salarizată, intervenție salutară, precum și incompatibilitatea vizând orice altă profesie autorizată sau salarizată. Conchidem astfel că, diferența dintre activitatea de conciliere și cea de mediere nu este una de substanță, în viziunea legiuitorului.

Noțiunea de management juridic este conexată de către autorii de specialitate13 cu activitatea de legiferare și aplicare a legilor. Aceste activități, privite în ansamblul lor, ca un sistem, ar presupune o conducere, într-un mediu organizațional, având o anumită structură, acest mediu fiind constituit în vederea realizării unor obiective. Beneficiile acestui sistem ar consta tocmai în posibilitatea de a analiza eficiența actului de conducere a activității, prin analizarea 
performanțelor obținute în cadrul sistemului, în raport de obiectivele propuse și procentul de realizare al acestora. Este, fără îndoiala, vorba despre un instrument adjuvant în asigurarea calității activităților cu specific juridic desfășurate de către diverși actori în sistemul de justiție românesc sau, de ce nu, în chiar procesul de legiferare.

În ceea ce privește activitatea de audit juridic, aceasta, fără a beneficia de o reglementare proprie, este desfășurată în momentul de față de către instituțiile și autoritățile publice, cu privire la activitatea juridică proprie, în cadrul misiunilor de audit intern, cu o periodicitate variabilă, în funcție de prevederile Legii nr. 672/2002 privind auditul public intern ${ }^{14}$. Referitor la societățile comerciale având capital majoritar privat, precum și la cele pe acțiuni, s-a conturat, în ultima perioadă, o practică a contractării unor astfel de audituri, realizate de către societăți profesionale de avocați. În concret, în cadrul unui astfel de audit juridic, verificările pot varia de la analiza situațiile litigioase în care firma sau societățile sale partenere sunt implicate sau au fost implicate, verificarea raporturilor contractuale în derulare în care societatea s-a angajat, identificarea și verificarea concordanței reglementărilor interne ale societății cu legislația aplicabilă în funcție de obiectul său de activitate.

Trecând la cel de-al doilea mod prin care consilierul juridic își va putea desfășura activitatea și care reprezintă un element de noutate absolută, spre deosebire de marea parte a actualului art. 10 care ar fi urmat să sufere doar reformulări, remarcăm faptul că acest profesionist al dreptului ar urma să poată conferi dată certă unei categorii de înscrisuri, și anume acelor înscrisuri care încorporează operațiuni juridice pentru a căror validitate este necesară această formalitate ${ }^{15}$. Din formularea art. 4 al. (1) lit. c) a proiectului de lege, reiese că, într-o formulare nefericită, odată cu atestarea conținutului și a identității părților prin aplicarea parafei profesionale, consilierul juridic va atesta data certă a unui act întocmit în numele entității juridice reprezentate. Considerăm că formularea corectă va pune accentul pe opozabilitatea actului față de terți, din momentul aplicării parafei profesionale și al consemnării în registrul profesional corespunzător. Această soluție este în concordanță și cu prevederile art. 278 Noul Cod de procedură civilă.

Referitor la aceste modificări, U.N.B.R. a emis o opinie ${ }^{16}$, o poziție fundamentată pe Decizia ICCJ nr. 22/2006 care prevede că „activitățile juridice de consultanță, de reprezentare și asistență juridică, precum și de redactare de acte juridice, inclusiv a acțiunilor introductive în instanță, cu posibilitatea atestării identității părților, a conținutului și a datei actelor, apărarea și reprezentarea cu mijloace juridice a drepturilor și intereselor legitime ale persoanelor fizice și juridice, în raporturile cu autoritățile publice, cu instituțiile și cu orice persoană română sau străină, constituie... activități specifice profesiei de avocat, reglementate în art. 3 din Legea nr. 51/1995, cu modificările și completările ulterioare, ...". Astfel, încercarea de liberalizare a profesiei de consilier juridic, prin introducerea unei noi forme de exercitare a profesiei (societăți profesionale), precum și prerogativa conferirii datei certe unor anumite categorii de acte reprezintă, de fapt, preluarea unor atribuții specifice profesiei de avocat, lucru care, în esență, este incorect și golește Legea nr. 51/1995 de conținut.

Punctul de vedere a fost însușit și de către alți membri ai baroului ${ }^{17}$ care au subliniat inutilitatea și redundanța creării unei structuri paralele cu cea a avocaților. $\mathrm{Cu}$ toate că au trecut mai bine de 6 luni de la trimiterea proiectului la Cameră pentru dezbatere, 
niciun reprezentant al organizației profesionale a consilierilor juridici nu a comentat scopul modificărilor propuse.

Alte modificări introduse prin acest proiect privesc obligativitatea înscrierii în organizația profesională pentru a putea utiliza titlul profesional ${ }^{18}$ și impunerea condiției promovării unui examen pentru accesul în profesie. Se poate observa că, reglementarea propusă contribuie la dezideratul privind exercitarea profesiei cu sprijinul unui cadru asociativ organizat, responsabil pentru asigurarea standardelor corespunzătoare privind pregătirea profesională a consilierului juridic. Asemănarea din acest punct de vedere, al legilor nr. 514/2003 și nr. 51/1995, este justificată din perspectiva atribuțiilor de reprezentare în fața instanțelor judecătorești, ce caracterizează ambii profesioniști, în calitatea lor de participanți la înfăptuirea actului de justiție. Mai mult chiar, cele doua profesii nu sunt la o primă evoluție tangențială. în anul 2007 dl. avocat prof. dr. Gheorghe Piperea a fost nominalizat de către decanul Baroului București, Cristian lordănescu, ca alături de secretarul general al Colegiului Consilierilor Juridici București, Lucian Florescu, să întocmească un proiect de lege care să prevadă unificarea profesiilor în discuție ${ }^{19}$. Inițiativa a fost pornită la sugestia președintelui American Barr Association, urmând modelul american.

Asupra proiectului de lege s-au pronunțat și comisiile parlamentare de specialitate, avizând negativ textul propunerii, din motive nespecificate ${ }^{20}$. Guvernul a emis un punct de vedere de asemenea negativ. Principalele critici au vizat similitudinile nejustificate dintre profesia de consilier juridic astfel reformata și cea de avocat, tehnica legislativă care lasă loc ambiguităților în interpretare și, nu în ultimul rând, lacunele dispozițiilor legale ${ }^{21}$. În acest sens, autoritatea executivului a criticat eliminarea din corpul legii a specificului activității consilierului juridic, astfel cum este consacrat în forma în vigoare a Legii nr. 514/2003, la art. $1^{22}$.

Spre deosebire de PI. x - nr. 312/2010, modificările cuprinse în Legea nr. 138/2016 depășesc sfera teoreticului, a schimbărilor de ordin formal în ceea ce privește statutul consilierului juridic și a calificării acestuia ca independent profesional, în raport cu entitățile în care își desfășoară activitatea. Articolele vizate aduc o varietate salutară în modurile de realizare a activității profesionale, precum și în formele de exercitare a profesiei. Ca orice formă liberală de exercitare a profesiei, societatea de consilieri juridici trebuie să aibă potențialul de a asigura o pregătire profesională adecvată a salariaților săi, în paralel cu desfășurarea obișnuită a activității cotidiene, activitate care nu este desfășurată în exclusivitate de către acești profesioniști. Situația nu este decât favorabilă unui mediu concurențial ale cărui beneficii se vor releva pe parcurs.

Concentrată asupra reglementării acestei noi posibilități și lacunară în ceea ce privește asigurarea unor standarde superioare în exercitarea profesiei de consilier juridic, Legea nr. 138/2016 ar urma să introducă doar un examen de acces în profesie, precum și obligativitatea înscrierii în Colegiile Consilierilor juridici, membre ale Ordinului Consilierilor juridici, pentru a putea utiliza titlul profesional. Ori, utilitatea acestor prevederi în asigurarea unui cadru unitar este subliniată de câțiva ani. În aceste condiții, exprimăm rezerve cu privire la caracterul adecvat al cadrului legislativ în care ar urma să fie adoptate aceste modificări.

\footnotetext{
*andra.huidan@yahoo.ro.
} 
${ }^{1} \mathrm{http}: / /$ www.cameradeputatilor.ro/pls/proiecte/upl_pck.proiect?idp=11074\&cam=2

${ }^{2}$ http://www.senat.ro/legis/lista.aspx?nr_cls=L138\&an_cls=2016

${ }^{3}$ http://coduri-cor.com/

${ }^{4}$ http://www.cdep.ro/proiecte/bp/2009/300/70/4/pl374.pdf

${ }^{5}$ Ș. Beligrădeanu, Considerații în legătură cu Legea nr. 514/2003 privind organizarea si exercitarea profesiei de consilier juridic, Dreptul nr. 2/2004, pag. 14 și urmatoarele.

${ }^{6}$ L. Florescu, Consilier juridic versus Avocat. Societati profesionale ale consilierilor juridici versus contracte de asistenta ale societatilor de avocatura cu institutii statale, articol disponibil la adresa : http://www.universuljuridic.ro/consilier-juridic-versus-avocat/

${ }^{7}$ S. I. Gidro, Motiv de cugetare : proiectul de modificare a Legii Consilierilor Juridici, disponibil la adresa: https://www.juridice.ro/420467/proiectul-de-lege-pentru-modificarea-legii-nr-5142003-privindorganizarea-si-exercitarea-profesiei-de-consilier-juridic-motiv-de-cugetare.html

${ }^{8}$ Expunerea de motive a proiectului, document disponibil la adresa : http://www.senat.ro/legis/PDF/2016/16L138EM.pdf

${ }^{9}$ http://www.senat.ro/legis/lista.aspx?nr_cls=L138\&an_cls=2016

${ }^{10}$ Proiectul de lege a fost respins in sedinta Senatului din data de 27.06 .2016 si se afla in prezent in stadiu de dezbatere, informatii disponibile la adresa : http://www.senat.ro/legis/lista.aspx?nr_cls=L138\&an_cls=2016

${ }^{11} \mathrm{M}$. Enache, Societate profesionala de avocati in loc de Societate civila de avocati, disponibil la adresa https://www.juridice.ro/226573/societate-profesionala-de-avocati-in-loc-de-societatecivila-de-avocati.html

${ }^{12}$ Art. 13

Exercitarea profesiei de mediator este compatibila cu orice alta activitate sau profesie, cu exceptia incompatibilitatilor prevazute prin legi speciale.

${ }^{13}$ V. Patulea, Tratat de management juridic si jurisdictional, Editura I.R.D.O, Bucuresti, 2010, pag. 110 si urmatoarele.

${ }^{14} \mathrm{~A}$ se vedea, spre exemplu, GHID PRACTIC MISIUNEA DE AUDIT INTERN PRIVIND ACTIVITATEA JURIDICĂ, elaborat de Ministerul Finantelor Publice, disponibil la adresa : http://discutii.mfinante.ro/static/10/Mfp/audit/Ghid_juridic_Ed_II.pdf

${ }^{15}$ Mentionam, cu titlu de exemplu, subrogatia consimtita de catre debitor.

$16 \mathrm{http}: / /$ uniuneabarourilor.ro/comunicatul-comisiei-permanente-a-unbr-cu-privire-la-propunerealegislativa-privind-modificarea-si-completarea-legii-nr-5142003-privind-organizarea-si-exercitareaprofesiei-de-consilier-juridic-pre/

${ }^{17}$ S. I. Gidro, op. cit.

${ }^{18}$ Lucru care se doreste a fi implementat încă de la prima încercare de reformare a cadrului legislativ in domeniu si ale carui beneficii pot fi cu greu trecute cu vederea, in conditiile unei nevoi tot mai pregnante de perfectionare profesionala intr-un cadru unitar, organizat. De altfel, chiar in sedinta Senatului, s-a reproșat acestor profesioniști că ar fi "cel mai slab pregatiti absolventi ai facultăților de drept".

19 L. Florescu: Profesia de consilier juridic este cea mai frumoasă profesie din lume, interviu disponibil la adresa : https://www.juridice.ro/410092/lucian-florescu-profesia-de-consilier-juridiceste-cea-mai-frumoasa-profesie-din-lume.html

${ }^{20}$ http://www.senat.ro/legis/PDF/2016/16L138ca15.pdf

${ }^{21}$ http://www.senat.ro/legis/PDF/2016/16L138PV.pdf

22 Art. 1 Consilierul juridic asigură apărarea drepturilor și intereselor legitime ale statului, ale autorităților publice centrale și locale, ale instituțiilor publice și de interes public, ale celorlalte persoane juridice de drept public, precum și ale persoanelor de drept privat, în slujba cărora se află și în conformitate cu Constituția și legile țării 